\title{
Evaluation of Solasonine Content and Expression Patterns of SGT1 Gene in Different Tissues of Two Iranian Eggplant (Solanum melongena L.) Genotypes
}

\author{
Mahmoud Bagheri ${ }^{1,2 *}$, Ali Akbar Shahnejat Bushehri ${ }^{1 *}$ \\ Mohammad Reza Hassandokht ${ }^{3}$ and Mohammad Reza Naghavi ${ }^{1}$ \\ ${ }^{1}$ Department of Agronomy and Plant Breeding, College of Agriculture and Natural Resources, \\ University of Tehran, Chamran Blvd., IR-31587-77871 Karaj, Iran \\ ${ }^{2}$ Seed and Plant Improvement Institute, Agricultural Research, \\ Education and Extension Organization (AREEO), Fahmideh Blvd., IR-31585-4119 Karaj, Iran \\ ${ }^{3}$ Department of Horticultural Sciences, College of Agriculture and Natural Resources, \\ University of Tehran, Chamran Blvd., IR-31587-77871 Karaj, Iran
}

Received: July 10, 2016 Accepted: February 15, 2017

\begin{abstract}
Summary
Eggplant (Solanum melongena L.) is one of the most consumed vegetables in the world. The eggplant glycoalkaloids (GAs) are toxic secondary metabolites that may have detrimental effects on human health, particularly if the magnitudes of GAs are higher than the recommended food safety level (200 $\mathrm{mg}$ per $\mathrm{kg}$ of fresh mass). In this study, the content of solasonine compound and the expression patterns of solasodine galactosyltransferase (SGT1) gene were assessed in different tissues (mature leaves, flower buds, young, mature, and physiologically ripe fruits) of two Iranian eggplant genotypes (D1 and J10) under field conditions. The maximum mass fraction of solasonine in D1 was detected in flower buds $(135.63 \mu \mathrm{g} / \mathrm{g})$, followed by leaf $(113.29 \mu \mathrm{g} / \mathrm{g})$, physiologically ripe fruit $(74.74 \mu \mathrm{g} / \mathrm{g})$, young fruit $(61.33 \mu \mathrm{g} / \mathrm{g})$, and mature fruit $(21.55 \mu \mathrm{g} / \mathrm{g})$. Comparing both genotypes, the genotype of bitter fruits (J10) contained higher mass fraction of solasonine, as one of the main factors for producing bitter flavour of the plant. Regarding the expression profiles of SGT1, in both genotypes, the activity of the gene was increased nearly parallel with the concentration of solasonine. In the J10 genotype, transcript level of the gene was significantly higher than the genotype of sweet fruits (D1). Although both D1 and J10 genotypes are possibly recommendable for human food consumption, D1 is more suitable for daily diet.
\end{abstract}

Key words: eggplant, gene expression, glycoalkaloids, SGT1 gene

\section{Introduction}

The family of Solanaceae (also known as nightshade family) is considered as a large plant family including essential crops such as potato, tomato, sweet pepper and lastly eggplant (1). In both tropical and temperate regions of the world, eggplant (Solanum melongena L., $2 \mathrm{n}=2 \mathrm{x}=24$ ) has been cultivated for years, and regarded currently as an economically important vegetable plant (2). Phylogenetically, contrary to the other important Solanaceae fam-

\footnotetext{
*Corresponding authors: Phone: +98 263670 2983; Fax: +98 263670 3776; E-mail: mahmoudbagheri@alumni.ut.ac.ir; Phone: +98 263222 7606; Fax: +98 263222 7605; E-mail: ashah@ut.ac.ir 
ily members including chili pepper, tomato, tobacco and potato, eggplant is believed to originate from the Old World (3).

The fruits of both eggplant and tomato, potato tubers and processed products are usually consumed as one of the main components of low-fat food, generating vitamins, fibre, energy, protein, as well as some bioactive constituents like steroidal glycoalkaloids (SGAs) (4). In addition, glycoalkaloids (GAs) are commonly generated in different tissues of the plant such as tubers, leaves, roots and sprouts (4-6). SGAs, as the main factor for producing bitter flavour in the fruits of Solanaceae family like eggplant (7), are believed to play fundamental roles in the defense mechanisms of the plants against pests and phytopathogens. In addition, they may also cause sporadic outbreaks of poisoning and therefore detrimental consequences on human health $(4,8,9)$. In fact, with a lethal dose of 3-5 mg per $\mathrm{kg}$ of body mass, SGAs are assumed as potent poisons, similar to arsenic and strychnine (10). A number of symptoms of SGA poisoning have been recorded, such as partial paralysis, gastrointestinal disorders, hallucinations, confusion, convulsions, coma and possibly death (9). As a result, prior to commercial release, new eggplant varieties need to be assessed regarding the quantity of naturally occurring poisonous constituents such as SGAs, and the same strategy has been recommended for potato (11). As both cooking and frying are not able to completely break down SGAs (12), in order to release new commercial varieties as safe as possible, an upper limit of $20 \mathrm{mg}$ per $100 \mathrm{~g}$ of fresh mass of potato tubers has been determined (13). From a positive point of view, SGAs may also have antioxidant activities, as more recently a number of anticancer activities have been widely recorded (6).

It is known that the accumulation and storage of alkaloids can change according to the type of alkaloid. Generally, alkaloids in plants are synthesised in specific tissues where the biosynthetic genes needed for specific alkaloids are expressed (14). After biosynthesis of alkaloids, they might accumulate at the site of synthesis or are transported to other specific tissues such as the leaves attacked by insects or herbivores (14-16).

SGA accumulation may be affected by a series of elements during growth, maturity and harvesting as well as post-harvest treatment. In addition, genotypes under study may play a key role, since SGA magnitudes may vary from one cultivar to another $(8,17)$. It has also been reported that various environmental conditions may affect SGA production/accumulation in Solanaceae family $(18,19)$. When GA content was analysed genetically, it proved to be highly heritable. According to the earlier work of Eltayeb et al. (20), SGA levels in potato appear to be modulated by several genes and influenced by dominant and recessive alleles as well. It has been demonstrated that the potato cultivars with high mass fractions of SGAs are more responsive against environmentally undesirable circumstances and accumulate them in higher amounts in the tubers than the cultivars with their low fractions (21).

Despite the significance of SGAs, studies on their biosynthetic pathway and the signals regulating SGA levels are still limited. It is also known that SGAs are normally generated in all parts of the eggplant, including the leaves, roots, fruits and sprouts, and that biosynthesis proceeds through the cholesterol pathway (8). However, many steps between cholesterol synthesis and formation of $\alpha$-solasonine and $\alpha$-solamargine are unknown. In general, in conjunction with at least 100 other Solanum species, it is believed that eggplants are capable enough of biologically synthesising the following two main steroid alkaloid glycosides (SAGs), namely solasonine and solamargine (22). From a structural perspective, both possess similar steroidal fragment of the molecule (aglycone), solasodine, while they differ in the nature of the carbohydrate side chain. In reality, so long as the two L-rhamnose followed by only one D-glucose moiety attach to 3-hydroxy position of solasodine, solamargine is formed. In contrast, solasonine can be formed when L-rhamnose and D-galactose moieties alongside one D-glucose moiety are linked to 3-hydroxy position of solasodine (23).

Gene expression-based studies are now regarded as a promising vehicle towards acquiring a deeper and more precise understanding of different mechanisms governing different complex regulatory networks of the genetic, signalling and metabolic pathways (24-26). Compared to other cultivated solanaceous plant species including pepper, tomato and potato, less information is available regarding gene expression analysis alongside SGA accumulation in eggplant. In fact, to the best of our knowledge, no study has been accomplished about simultaneous investigation of the influence of eggplant cultivar types on the expression of SGT1 (solasodine galactosyltransferase) gene, known to be involved in the solasonine synthesis from solasodine. Here, attempts were made to determine the production ratio of solasonine and also the expression of SGT1 gene in mature leaves, flower buds and young, mature, and physiologically ripe fruits of two Iranian eggplant genotypes under field conditions.

\section{Materials and Methods}

\section{Plant materials}

Two eggplant (Solanum melongena) genotypes, named D1 (sweet fruits) and J10 (bitter fruits), were used in this study. D1 and J10 are two selected genotypes from eggplant populations originating from Dezfoul and Jahrom cities of Iran, respectively. The seeds of both genotypes were sterilised by submerging in $10 \%$ sodium hypochlorite for $5 \mathrm{~min}$ and then immediately washed thrice using sterilised autoclaved water to remove disinfection liquid. Afterwards, the seeds were germinated in the field located at the greenhouse of Seed and Plant Improvement Institute (SPII), Karaj, Iran, beginning in mid-May, 2014. For each genotype, plant sampling of mature leaves, flower buds and young (before market stage), mature (market stage) and (physiologically ripe) fruits was performed. After harvesting, two fruits of each genotype were cut into slices with the thickness of approx. $1 \mathrm{~cm}$, freeze dried for $72 \mathrm{~h}$ and packaged under vacuum conditions, while leaf and flower bud samples were directly packed in aluminium foil. All the samples were then stored at $-80{ }^{\circ} \mathrm{C}$ until further analyses. 


\section{RNA isolation, quality assessment and cDNA synthesis}

Using a mortar with liquid nitrogen, $100 \mathrm{mg}$ of each tissue of each sample were initially homogenised to make a fine powder, and subsequently RNA isolation was carried out using a Trizol GeneAll (Seoul, Korea) according to manufacturer's instructions. Afterwards, DNase I, RNase-free DNase set (Fermentas, Waltham, MA, USA) was employed to remove putative genomic DNA contamination. Quality and quantity of the resultant RNAs were corroborated by means of a NanoDrop ${ }^{\circledast}$ ND-1000 spectrophotometer (Thermo Fisher Scientific, Wilmington, DE, USA). The first-strand cDNA synthesis was undertaken using $1.0 \mu \mathrm{g}$ of total RNA (27). Briefly, the mixture comprising DNase I (Fermentas, Waltham, MA, USA) was allowed to heat up to $37^{\circ} \mathrm{C}$ for $30 \mathrm{~min}$, and subsequently the temperature was increased up to $65^{\circ} \mathrm{C}$ for $10 \mathrm{~min}$ to stop the enzyme activity. Afterwards, based on the manufacturer's instructions, cDNA synthesis was performed via the addition of $200 \mathrm{U} / \mu \mathrm{L}$ of reverse transcriptase enzyme (Fermentas, Vilnius, Lithuania) alongside $0.5 \mu \mathrm{g} / \mu \mathrm{L}$ of oligo(dT) primer (Thermo Fisher Scientific, Wilmington, DE, USA) to the mixture and allowed to heat up to 40 ${ }^{\circ} \mathrm{C}$ for $60 \mathrm{~min}$ and then to $95^{\circ} \mathrm{C}$ for $5 \mathrm{~min}$. Finally, all the cDNA samples were diluted to $400 \mathrm{ng} / \mu \mathrm{L}$ working concentration and stored at $-20^{\circ} \mathrm{C}$ for short-term and at -80 ${ }^{\circ} \mathrm{C}$ for long-term period, until further analyses.

\section{Primer design and quantitative real-time PCR}

The primer sequences were designed on the basis of the corresponding gene, SGT1, using PrimerQuest software (28), as fully described in Table 1 . To verify the secondary structures of the primers, Oligo Analyzer software was used (28). Furthermore, the mature fruits were selected as the control, and the cyclophilin (CYP) gene was utilised as reference gene. Remarkably, PCR efficiencies of the samples with the quantities equal to or more than 0.8 $(80 \%)$ were considered for quantification of gene expression, as could be automatically computed via real-time PCR machine (Rotor-Gene Q; QIAGEN, Hilden, Germany) (26). The experiments were performed in four technical replicates, and gene expression assay was accomplished with REST software (29). The quantitative real-time PCR (qRT-PCR) amplification was carried out by means of a real-time PCR system (Rotor-Gene Q; QIAGEN), with a final volume of $20 \mu \mathrm{L}$ for each reaction comprising $4 \mu \mathrm{L}$ of the previously diluted cDNAs, $4 \mu \mathrm{L}$ of EvaGreen Master Mix (containing EvaGreen Dye, Solis BioDyne, Tartu, Estonia), $0.25 \mu \mathrm{M}$ of each forward and reverse primer and the addition of PCR-grade water. The temperature program of qRT-PCR was set at $15 \mathrm{~min}$ at $95^{\circ} \mathrm{C}$, in conjunction with 40 cycles of $95^{\circ} \mathrm{C}$ for $20 \mathrm{~s}, 58^{\circ} \mathrm{C}$ for $20 \mathrm{~s}$ and 72 ${ }^{\circ} \mathrm{C}$ for $20 \mathrm{~s}$, and final melting curve between 72 and $95^{\circ} \mathrm{C}$.

\section{Extraction of glycoalkaloids}

For GA extraction, $1000 \mathrm{mg}$ of fruit, leaf or flower bud powder of each genotype were mixed with $40 \mathrm{~mL}$ of solution of $5 \%$ acetic acid in methanol in a 50-mL Falcon tube. Then, the resulting mixtures were put on a shaker at 400 rpm overnight. The next day, the resulting mixtures were shaken at $600 \mathrm{rpm}$ for $10 \mathrm{~min}$ and subsequently filtered through 90-mm filter paper (Schleicher \& Schuell BioScience $\mathrm{GmbH}$, Dassel, Germany) via a Büchner funnel and vacuum pump. Subsequently, each sample was filtered using $0.45-\mu \mathrm{m}$ polyamide filter (Schleicher \& Schuell BioScience $\mathrm{GmbH}$ ) and vacuum pump. Finally, two tubes of each sample were mixed in a rotary flask and evaporated with a rotary evaporator (Laborota 4001; Heidolph, Schwabach, Germany) until the volume of $8-9 \mathrm{~mL}$ was obtained. Then, each sample was filtered with a $0.2-\mu \mathrm{m}$ polyamide filter (Schleicher \& Schuell BioScience $\mathrm{GmbH}$ ) by using vacuum pump, transferred into $10-\mathrm{mL}$ volumetric flask and diluted to $10 \mathrm{~mL}$ with $5 \%$ acetic acid in methanol. After dilution, the extract was kept at $4{ }^{\circ} \mathrm{C}$ until HPLC analysis. For each sample, two extractions were done to check reproducibility.

\section{HPLC assay and solasonine measurement}

For HPLC analysis, a Shimadzu Class-VP (Kyoto, Japan) single-piston high-pressure liquid chromatograph with photodiode array detection and C18 column was utilised. For glycoalkaloid analysis, UV detection at 205 and $208 \mathrm{~nm}$ was chosen. Flow rate and temperature were set to $1.0 \mathrm{~mL} / \mathrm{min}$ and $50{ }^{\circ} \mathrm{C}$, respectively. Acetonitrile/10 \% methanol in a ratio of $1: 1$ and $100 \mathrm{mM}$ ammonium dihidrogen phosphate buffer $(\mathrm{pH}=2.58)$ were used as mobile phase. While preparing $100 \mathrm{mM}$ ammonium dihydrogen phosphate buffer, $\mathrm{pH}$ was adjusted with orthophosphoric acid $(85 \%)$. After the $\mathrm{pH}$ was adjusted, the buffer was filtered through polyamide filter (Schleicher \& Schuell BioScience $\mathrm{GmbH}$ ) by using vacuum pump. Then, both acetonitrile/methanol and ammonium dihydrogen phosphate buffer were put into ultrasonic bath to remove the bubbles from these solutions. When all the bubbles were removed, the A pump filter was put into ammonium dihidrogen phosphate buffer, and the B pump filter was inserted into acetonitrile $/ 10 \%$ methanol (1:1). For glycoalkaloid analysis, B and A pumps were set at 70 and $30 \%$ capacity, respectively. Every day the column was washed with mobile phase for $40 \mathrm{~min}$ at a flow rate of $1.0 \mathrm{~mL} / \mathrm{min}$. Then, 5 $\%$ acetic acid in methanol used as a blank was injected into the HPLC and samples were measured. In addition, standard stock solution $(1.0 \mathrm{mg} / \mathrm{mL})$ of solasonine was prepared in acetonitrile/water (1:1 by volume) containing one drop of ortho-phosphoric acid ( $85 \%$ ) to adjust the $\mathrm{pH}$ to 2 and stored at $4{ }^{\circ} \mathrm{C}$. It was added into samples for

Table 1. Primer sequences and related characteristics used in the study

\begin{tabular}{llllc}
\hline Gene & Gene description & Primer sequence $\left(5^{\prime}-3^{\prime}\right)$ & $t_{\mathrm{m}} /{ }^{\circ} \mathrm{C}$ & Amplicon length/bp \\
\hline \multirow{2}{*}{ SGT1 } & Solasodine galactosyltransferase & $\begin{array}{l}\text { F: ATACCAGCCAAGAATGTTGTT } \\
\text { R: CATTTTGCAGGTGTTATCTT }\end{array}$ & 58 & 134 \\
\hline \multirow{2}{*}{ CYP } & Cyclophilin & F: ATCCTGTCCATGGCTAATGC & \multirow{2}{*}{ R: ATGCCCTCAACAACTTGTCC } & \multirow{2}{*}{119} \\
\hline
\end{tabular}

$t_{\mathrm{m}}=$ melting temperature 
spiking to calculate solasonine amount. For each sample, three HPLC measurements were done. After measuring each sample, the amount of solasonine in the sample was calculated. Peak areas of samples and samples with spikes were analysed and then the amounts of glycoalkaloids were calculated. Notably, solasonine standard for HPLC was provided by Dr. Michael Schwarz (Head of Reference Substances, PhytoLab GmbH \& Co. KG, Vestenbergsgreuth, Germany) and subsequently utilised to generate standard curves for quantification survey. In order to quantitatively determine solasonine content of each sample, the standard concentrations of $0,50,100,200$ and $1000 \mathrm{mg} / \mathrm{L}$ were prepared, and $\mathrm{R}=0.998$ was obtained for the standard calibration curve.

\section{Statistical analysis}

The data were analysed with one-way analysis of variance (ANOVA) to acquire possible significant differences (defined as $\mathrm{p} \leq 0.05$ ). The experiment was conducted on the basis of a completely randomised design (CRD) with three replications, and the resulting data were subsequently analysed using SAS software package (30). Meanwhile, to compare different tissues, Duncan's multiple range test $(p \leq 0.05)$ was utilised. For gene expression assay, four technical replicates were done, and the resulting data were analysed with REST software (29).

\section{Results and Discussion}

\section{Solasonine measurement}

In D1 genotype, the maximum amount of solasonine was detected in flower buds $(135.63 \mu \mathrm{g} / \mathrm{g})$, followed by leaf $(113.29 \mu \mathrm{g} / \mathrm{g})$, physiologically ripe fruit $(74.74 \mu \mathrm{g} / \mathrm{g})$, young fruit $(61.33 \mu \mathrm{g} / \mathrm{g})$ and mature fruit $(21.55 \mu \mathrm{g} / \mathrm{g})$ (Fig. 1). In addition, in J10 genotype, similar to D1, the highest mass fraction of solasonine was observed in flower buds $(478.81 \mu \mathrm{g} / \mathrm{g})$, followed by leaf $(249.32 \mu \mathrm{g} / \mathrm{g})$, physiologically ripe fruit $(185.03 \mu \mathrm{g} / \mathrm{g})$, young fruit $(160.39 \mu \mathrm{g} / \mathrm{g})$ and mature fruit (45.55 $\mu \mathrm{g} / \mathrm{g})$ (Fig. 1). However, comparing each tissue of both genotypes, J10 genotype produced much more solasonine than D1, particularly in flower buds and leaf.

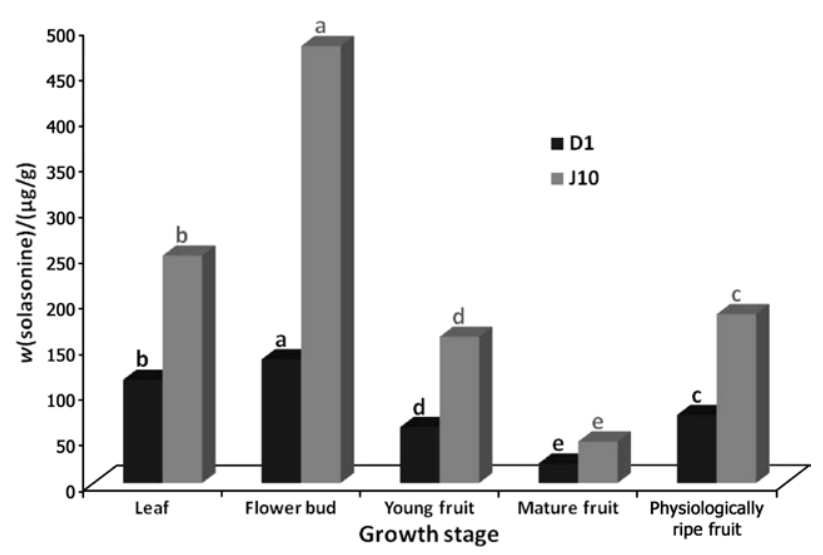

Fig. 1. Mass fractions of solasonine in both eggplant genotypes (D1 and J10) used in the study. Different letters above the bars represent statistically significant difference at $\mathrm{p} \leq 0.05$ (Duncan's multiple range test)
In general, the members of Solanaceae family are able to produce enough of different kinds of GAs. For instance, in potato (S. tuberosum L.), the major constituents of the GA family include trisaccharides $\alpha$-solanine, $\alpha$-chaconine, $\alpha$-tomatine and dehydrotomatine, which are commonly found in tomato, while in eggplants, $\alpha$-solasonine and $\alpha$-solamargine are the most abundant spirosolane-type GAs $(4,23,31)$. As mentioned before, SGAs can be found in all plant tissues, but they accumulate mainly in metabolically active tissues, including immature berries, flowers and young leaves or shoots. In addition, like other secondary plant metabolites $(16,32)$, both quality and quantity of GAs may vary either among various plant species or individuals, or among different tissues of a single plant during different growth and developmental phases. These variations may be due to the genotype/variety under study $(33,34)$, environmental conditions, locality $(11,35)$, ontogenetic alterations (i.e. 'genetically programmed developmental changes taking place during a plant's life') (36), resistance to viral and bacterial diseases $(37,38)$, insect inhibition (39), harvest and postharvest processes like drought (33), light exposure of the tubers (40) and wounding $(41,42)$.

In the current study, the production and accumulation of GAs like solasonine in eggplant does appear to be genotype- and tissue-dependent. In the study of Bejarano et al. (33), using six varieties of potato, it was found that all the varieties are capable of generating diverse amounts of both $\alpha$-solanine and $\alpha$-chaconine, but remarkably, the mass fraction of GA was still lower than the recommended food safety level (200 mg per $\mathrm{kg}$ of fresh tubers). In the same study, a substantial increase in the mass fraction of both GAs (i.e. $\alpha$-solanine and $\alpha$-chaconine) also occurred under water stress, leading to a conclusion that GA accumulation in potato could be affected by genotype and environmental stress like drought (33).

Safety assessment of allied species of S. aethiopicum and $S$. macrocarpon cultivated in Africa was carried out to analyse the major eggplant glycoalkaloids (i.e. solamargine and solasonine) (8). The results indicated that the fruits of S. aethiopicum and S. melongena contained (in $\mathrm{mg}$ per $100 \mathrm{~g}$ of fresh mass) $\alpha$-solamargine $(0.58-4.56)$ and $\alpha$-solasonine (0.17-1.0). In addition, as the quantities of both aforesaid metabolites in S. macrocarpon were 5-10 times greater than the quantity recommended as safe in foods, it was eventually emphasised that this species might not be safe for human consumption (8). Similarly, comparing 10 eggplant lines with three allied species $(S$. aethiopicum, S. integrifolium and S. sodomaeum), it was concluded that the allied species had higher glycoalkaloid quantities than the widely consumed eggplants and that the glycoalkaloid content generally increased during fruit development and ripening (43). On the other hand, the quantities of solasonine decreased during fruit maturation in both D1 and J10 genotypes. To explain this phenomenon, it has been demonstrated that during fruit maturation, GAs like solasonine are converted into nitrogen-free and non-toxic composites (44). Finally, according to the recommended food safety level (200 $\mathrm{mg}$ per $\mathrm{kg}$ ), although both D1 and J10 genotypes are recommendable for human food consumption, D1 is more suitable for human daily diet. 


\section{Expression profiling of SGT1 gene}

In order to assess probable associations between the expression patterns of SGT1 gene and solasonine accumulation in both investigated eggplant genotypes, relative gene expression analysis was performed using qRT-PCR.

Taking mature fruit of D1 genotype as reference value for both genotypes, the maximum relative expression ratio of SGT1 gene occurred in flower buds of D1 genotype with the fold change value of 10.00, whereas in the physiologically ripe fruit (6.45-fold), leaf (5.45-fold) and young fruit (3.99-fold), the gene exhibited lower activities (Fig. 2). In J10, similar to the D1, the highest relative transcript levels of SGT1 gene (94.11-fold) were obtained when cDNAs of flower buds were profiled using qRT-PCR (Fig. 2). Transcript levels of this gene in other tissues decreased, as the fold change quantities of 49.72, 36.25, 21.82 and 14.97 were calculated for leaf, physiologically ripe fruit, young fruit and mature fruit, respectively (Fig. 2). Comparing J10 and D1 of each tissue, the expression frequency of SGT1 gene of J10 was superior to D1, albeit some fluctuations could be observed. For instance, the maximum relative expression ratio was observed in mature fruit (14.97), while in both leaf (9.11) and flower buds (9.7) moderate ratios were observed, and finally the lowest ratio occurred in fruits (5.48) and young fruits (5.47).

Comparing the results of solasonine content and SGT1 gene expression results, significant association was found between the activity of SGT1 gene and solasonine generation/accumulation in both genotypes. Therefore, we can conclude that solasonine content significantly depends on SGT1 activity, that during ontogenetic changes of the plant, particularly fruit maturation, SGT1 activity is decreased and that some amounts of solasonine are possibly catalysed. In the edible potato tuber samples with different total glycoalkaloid (TGA) contents, the relative expression ratio of GAME4, GAME6, GAME7, GAME8a, GAME8b, GAME11, GAME12, SGT3 and SGT1 has recently been assessed using qPCR (qRT-PCR) (11). With the exception of $G A M E 7$, all the other genes exhibited higher relative expression levels in samples with higher TGA contents ( $\alpha=0.05$, t-test), which is in agreement with our results.

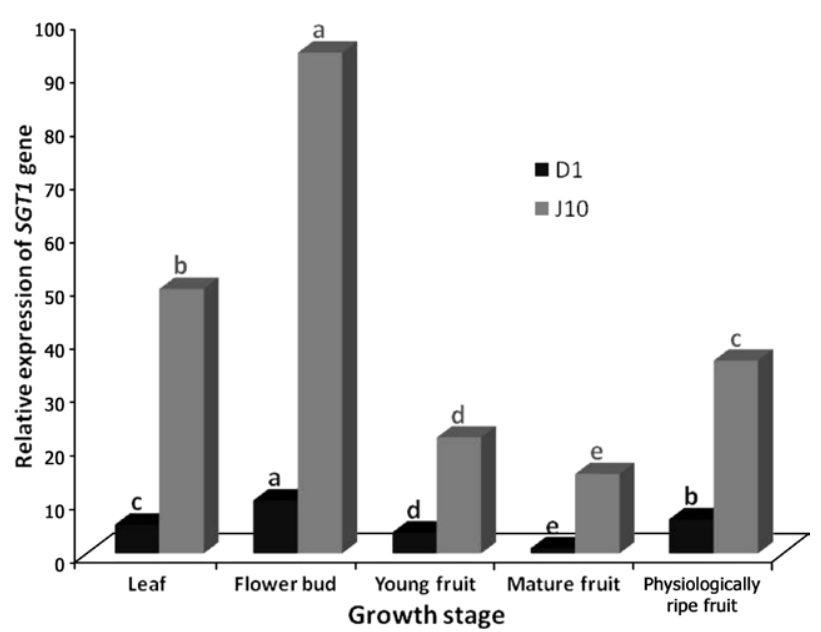

Fig. 2. Differential expression levels of the SGT1 gene in D1 and J10 eggplant genotypes under field conditions. Different letters above the bars represent statistically significant difference at $\mathrm{p} \leq 0.05$ (Duncan's multiple range test)

\section{Conclusion}

In conclusion, two Iranian eggplant genotypes with different strength of bitter fruit flavour were used to examine their solasonine content as well as to elucidate the expression pattern of the corresponding gene, SGT1, during ontogenetic changes. As expected, the genotype with stronger bitterness had higher content of solasonine, while the other one had lower levels. It was also concluded that during fruit maturation the solasonine content tends to decrease, as the lowest mass fraction of solasonine occurred in mature fruits of both genotypes. Such phenomenon is presumably because of the conversion of glycoalkaloids like solasonine into nitrogen-free, non-toxic compounds. Since the sweet fruit eggplant (D1) contained lower amounts of solasonine than the bitter one (J10), it is more suitable for human daily diet.

\section{Acknowledgement}

The authors would like to acknowledge the Seed and Plant Improvement Institute (SPII) and the University of Tehran for the financial support of this work.

\section{References}

1. Simonovska B, Vovk I. High-performance thin-layer chromatographic determination of potato glycoalkaloids. J Chromatogr A. 2000;903:219-25.

https://doi.org/10.1016/S0021-9673(00)00900-6

2. Salunkhe DK, Kadam SS. Handbook of vegetable science and technology: production, compostion, storage, and processing. Boca Raton, FL, USA: CRC Press; 1998.

3. Hirakawa H, Shirasawa K, Miyatake K, Nunome T, Negoro S, Ohyama A, et al. Draft genome sequence of eggplant (Solanum melongena L.): the representative Solanum species indigenous to the old world. DNA Res. 2014;21:649-60. https://doi.org/10.1093/dnares/dsu027

4. Friedman M. Chemistry and anticarcinogenic mechanisms of glycoalkaloids produced by eggplants, potatoes, and tomatoes. J Agric Food Chem. 2015;63:3323-37. https://doi.org/10.1021/acs.jafc.5b00818

5. Distl M, Wink M. Identification and quantification of steroidal alkaloids from wild tuber-bearing Solanum species by HPLC and LC-ESI-MS. Potato Res. 2009;52:79-104. https://doi.org/10.1007/s11540-008-9123-0

6. Sucha L, Tomsik P. The steroidal glycoalkaloids from solanaceae: toxic effect, antitumour activity and mechanism of action. Planta Med. 2016;82:379-87. https://doi.org/10.1055/s-0042-100810

7. Knuthsen P, Jensen U, Schmidt B, Larsen IK. Glycoalkaloids in potatoes: content of glycoalkaloids in potatoes for consumption. J Food Compos Anal. 2009;22:577-81. https://doi.org/10.1016/j.jfca.2008.10.003

8. Sánchez-Mata MC, Yokoyama WE, Hong YJ, Prohens J. $\alpha$-Solasonine and $\alpha$-solamargine contents of gboma (Solanum macrocarpon L.) and scarlet (Solanum aethiopicum L.) eggplants. J Agric Food Chem. 2010;58:5502-8. https://doi.org/10.1021/jf100709g

9. Smith DB, Roddick JG, Jones JL. Potato glycoalkaloids: some unanswered questions. Trends Food Sci Tech. 1996;7:126-31. https://doi.org/10.1016/0924-2244(96)10013-3

10. WHO Technical Report No. 828. Evaluation of certain food additives and naturally occurring toxicants. 39th report of the Joint FAO/WHO Expert Committee on Food Additives. 
Geneva, Switzerland: Food and Agriculture Organization of the United Nations and World Health Organization (FAO/ WHO). 1992. Available from: apps.who.int/iris/bitstream/ 10665/40033/1/WHO_TRS_828.pdf.

11. Mariot RF, de Oliveira LA, Voorhuijzen MM, Staats M, Hutten RCB, van Dijk JP, et al. Characterization and transcriptional profile of genes involved on glycoalkaloid biosynthesis in new varieties of Solanum tuberosum L. J Agric Food Chem. 2016;64:988-96.

https://doi.org/10.1021/acs.jafc.5b05519

12. Maga JA. Glycoalkaloids in solanaceae. Food Rev Int. 1994; 10:385-418.

https://doi.org/10.1080/87559129409541010

13. Valkonen JPT, Keskitalo M, Vasara T, Pietilä L, Raman KV. Potato glycoalkaloids: a burden or a blessing? Crit Rev Plant Sci. 1996;15:1-20. https://doi.org/10.1080/07352689609701934

14. Yazaki K. ABC transporters involved in the transport of plant secondary metabolites. FEBS Lett. 2006;580:1183-91. https://doi.org/10.1016/j.febslet.2005.12.009

15. De Luca V, Laflamme P. The expanding universe of alkaloid biosynthesis. Curr Opin Plant Biol. 2001;4:225-33. https://doi.org/10.1016/S1369-5266(00)00165-5

16. Rezaei M, Naghavi MR, Hoseinzade AH, Abbasi A. Developmental accumulation of thebaine and some gene transcripts in different organs of Papaver bracteatum. Ind Crops Prod. 2016;80:262-8. https://doi.org/10.1016/j.indcrop.2015.11.009

17. Lee KR, Kozukue N, Han JS, Park JH, Chang EY, Baek EJ, et al. Glycoalkaloids and metabolites inhibit the growth of human colon (HT29) and liver (HepG2) cancer cells. J Agric Food Chem. 2004;52:2832-9.

https://doi.org/10.1021/jf030526d

18. Laurila J. Interspecific hybrids of potato: determination of glycoalkaloid aglycones and influence of bacterial infection [PhD Thesis]. Helsinki, Finland: University of Helsinki; 2004.

19. Machado RMD, Toledo MCF, Garcia LC. Effect of light and temperature on the formation of glycoalkaloids in potato tubers. Food Control. 2007;18:503-8. https://doi.org/10.1016/j.foodcont.2005.12.008

20. Eltayeb EA, Al-Sinani SS, Khan I. Effect of illumination by fluorescent light on the accumulation of glycoalkaloids in the tubers of 7 varieties of potato (Solanum tuberosum L.) grown in Oman. Pak J Biol Sci. 2003;7:655-60. https://doi.org/10.3923/pjbs.2003.655.660

21. Papathanasiou F, Mitchell SH, Harvey BMR. Variation in glycoalkaloid concentration of potato tubers harvested from mature plants. J Sci Food Agric. 1999;79:32-6. https://doi.org/10.1002/(SICI)1097-0010(199901)79:1<32: :AID-JSFA162>3.0.CO;2-J

22. Blankemeyer J, McWilliams ML, Rayburn JR, Weissenberg M, Friedman M. Developmental toxicology of solamargine and solasonine glycoalkaloids in frog embryos. Food Chem Toxicol. 1998;36:383-9.

https://doi.org/10.1016/S0278-6915(97)00164-6

23. Friedman M. Potato glycoalkaloids and metabolites: roles in the plant and in the diet. J Agric Food Chem. 2006;54:865581.

https://doi.org/10.1021/jf061471t

24. Wan H, Zhao Z, Qian C, Sui Y, Malik AA, Chen J. Selection of appropriate reference genes for gene expression studies by quantitative real-time polymerase chain reaction in $\mathrm{cu}$ cumber. Anal Biochem. 2010;399:257-61. https://doi.org/10.1016/j.ab.2009.12.008

25. Yeap WC, Loo JM, Wong YC, Kulaveerasingam H. Evaluation of suitable reference genes for qRT-PCR gene expression normalization in reproductive, vegetative tissues and during fruit development in oil palm. Plant Cell Tiss Organ Cult. 2014;116:55-66.

https://doi.org/10.1007/s11240-013-0382-3

26. Nasiri J, Naghavi MR, Alizadeh H, Moghadam MRF. Seasonal-based temporal changes fluctuate expression patterns of TXS, DBAT, BAPT and DBTNBT genes alongside production of associated taxanes in Taxus baccata. Plant Cell Rep. 2016;35:1103-19. https://doi.org/10.1007/s00299-016-1941-y

27. Goojani HG, Javaran MJ, Nasiri J, Goojani EG, Alizadeh H. Expression and large-scale production of human tissue plasminogen activator ( $\mathrm{t}-\mathrm{PA}$ ) in transgenic tobacco plants using different signal peptides. Appl Biochem Biotechnol. 2013; 169:1940-51.

https://doi.org/10.1007/s12010-013-0115-4

28. Owczarzy R, Tataurov AV, Wu Y, Manthey JA, McQuisten KA, Almabrazi HG, et al. IDT SciTools: a suite for analysis and design of nucleic acid oligomers. Nucleic Acids Res. 2008;36:W163-9. https://doi.org/10.1093/nar/gkn198

29. Pfaffl MW, Horgan GW, Dempfle L. Relative expression software tool $\left(\right.$ REST $\left.^{\circ}\right)$ for group-wise comparison and statistical analysis of relative expression results in real-time PCR. Nucleic Acids Res. 2002;30:e36. https://doi.org/10.1093/nar/30.9.e36

30. Khattree R, Naik DN. Multivariate data reduction and discrimination with $\mathrm{SAS}^{\circledR}$ software. SAS Institute; 2000.

31. Friedman M. Tomato glycoalkaloids: role in the plant and in the diet. J Agric Food Chem. 2002;50:5751-80.

https://doi.org/10.1021/jf020560c

32. Ranjbar M, Naghavi MR, Alizadeh H, Soltanloo H. Expression of artemisinin biosynthesis genes in eight Artemisia species at three developmental stages. Ind Crops Prod. 2015;76: 836-43. https://doi.org/10.1016/j.indcrop.2015.07.077

33. Bejarano L, Mignolet E, Devaux A, Espinola N, Carrasco E, Larondelle Y. Glycoalkaloids in potato tubers: the effect of variety and drought stress on the $\alpha$-solanine and $\alpha$-chaconine contents of potatoes. J Sci Food Agric. 2000;80:2096-100. https://doi.org/10.1002/1097-0010(200011)80:14<2096::AIDJSFA757>3.0.CO;2-6

34. Talebi Kouyakhi E, Naghavi MR, Alayhs M. Study of the essential oil variation of Ferula gummosa samples from Iran. Chem Nat Compd. 2008;44:124-6.

https://doi.org/10.1007/s10600-008-0038-4

35. Baghalian K, Haghiry A, Naghavi MR, Mohammadi A. Effect of saline irrigation water on agronomical and phytochemical characters of chamomile (Matricaria recutita L.). Sci Hortic. 2008;116:437-41. https://doi.org/10.1016/j.scienta.2008.02.014

36. Koricheva J, Barton KE. Temporal changes in plant secondary metabolite production. In: Iason GR, Dicke M, Hartley SE, editors. The ecology of plant secondary metabolites: From genes to global processes. Cambridge, UK: Cambridge University Press; 2012. pp. 34-55.

https://doi.org/10.1017/CBO9780511675751.004

37. Austin S, Lojkowska E, Ehlenfeldt MK, Kelman A, Helgeson JP. Fertile interspecific somatic hybrids of Solanum: a novel source of resistance to Erwinia soft rot. Phytopathology. 1988; 78:1216-20.

https://doi.org/10.1094/Phyto-78-1216

38. Pehu E, Gibson RW, Jones MGK, Karp A. Studies on the genetic basis of resistance to potato leaf roll virus, potato virus $\mathrm{Y}$ and potato virus $\mathrm{X}$ in Solanum brevidens using somatic hybrids of Solanum brevidens and Solanum tuberosum. Plant Sci. 1990;69:95-101.

https://doi.org/10.1016/0168-9452(90)90107-Y 
39. Nenaah G. Individual and synergistic toxicity of solanaceous glycoalkaloids against two coleopteran stored-product insects. J Pest Sci. 2011;84:77-86.

https://doi.org/10.1007/s10340-010-0329-y

40. Dale MFB, Griffiths DW, Bain H, Todd D. Glycoalkaloid increase in Solarium tuberosum on exposure to light. Ann Appl Biol. 1993;123:411-8. https://doi.org/10.1111/j.1744-7348.1993.tb04103.x

41. Choi D, Bostock RM, Avdiushko S, Hildebrand DF. Lipidderived signals that discriminate wound- and pathogen-responsive isoprenoid pathways in plants: methyl jasmonate and the fungal elicitor arachidonic acid induce different 3-hydroxy-3-methylglutaryl-coenzyme A reductase genes and antimicrobial isoprenoids in Solanum tuberosum $\mathrm{L}$. Proc Natl Acad Sci USA. 1994;91:2329-33. https://doi.org/10.1073/pnas.91.6.2329
42. Hashemi SM, Naghavi MR. Production and gene expression of morphinan alkaloids in hairy root culture of Papaver orientale L. using abiotic elicitors. Plant Cell Tiss Organ Cult. 2016;125:31-41.

https://doi.org/10.1007/s11240-015-0927-8

43. Mennella G, Lo Scalzo R, Fibiani M, D'Alessandro A, Francese G, Toppino $L$, et al. Chemical and bioactive quality traits during fruit ripening in eggplant (S. melongena L.) and allied species. J Agric Food Chem. 2012;60:11821-31. https://doi.org/10.1021/jf3037424

44. Dinan L, Harmatha J, Lafont R. Chromatographic procedures for the isolation of plant steroids. J Chromatogr A. 2001; 935:105-23.

https://doi.org/10.1016/S0021-9673(01)00992-X 